\title{
Giberellik Asit Ön Uygulamasına Tabi Tutulmuş Hüsnüyusuf (Dianthus Barbatus L.) Tohumlarının Tuz Stresinde Çimlenmesi
}

\author{
Suzan YILDIZ ${ }^{1}$, Fazilet PARLAKOVA KARAGÖZ ${ }^{1 *}$, Atilla DURSUN ${ }^{2}$ \\ ${ }^{1}$ Atatürk Üniversitesi Fen Bilimleri Enstitüsü Bahçe Bitkileri Ana Bilim Dalı, Erzurum \\ ${ }^{2}$ Atatürk Üniversitesi Ziraat Fakültesi Bahçe Bitkileri Bölümü, Erzurum \\ (*Sorumlu yazar e-mail: f.parlakova@atauni.edu.tr)
}

Geliş Tarihi : 13.08.2016

Kabul Tarihi : 15.01.2017

\begin{abstract}
ÖZET : $\mathrm{Bu}$ araștırma, Hüsnüyusuf (Dianthus barbatus L.) tohumlarına $\mathrm{GA}_{3}$ 'in çimlenme öncesinde uygulanmasının, tuzlu koşullarda tohum çimlenmesi üzerine etkisini belirlemek amacıyla yürütülmüştür. Bitkisel materyal olarak Hüsnüyusuf (Dianthus barbatus $\mathrm{L}$.) tohumları kullanılmış ve tohumlar dokuz farklı uygulamaya tabi tutulmuştur. Çalışmada, 40 ppm $\mathrm{GA}_{3}$ ön uygulaması yapılmış ve saf su ile sulanan hüsnüyusuf tohumlarının çimlenme oranı (\% 83.50) en yüksek bulunurken; en düşük çimlenme oranı (\% 4.00) saf su ön uygulaması yapılmış ve $100 \mathrm{mM} \mathrm{NaCI}$ ile sulanan tohumlarda belirlenmiştir. Ortalama çimlenme süresi ise 3.10 (gün) ile en düșük olarak 20 ppm $\mathrm{GA}_{3}$ ön uygulaması yapılmış ve saf su ile sulanan hüsnüyusuf tohumlarında tespit edilmiştir. Tuzluluk, konsantrasyona bağlı olarak hüsnüyusuf tohumlarının çimlenmesini engellemiştir. Çimlenme öncesi yaptı̆̆ımız $\mathrm{GA}_{3}$ ön uygulamalarının, tuz stresinin hüsnüyusuf tohumlarının çimlenme engelleyici etkisini önemli ölçüde ortadan kaldırdığı saptanmıştır.
\end{abstract}

Anahtar kelimeler: Dianthus barbatus L., giberrellik asit $\left(\mathrm{GA}_{3}\right)$, tohum çimlenmesi, tuz stresi

\section{Germination in Salt Stress of Sweet William (Dianthus barbatus L.) Seeds Applied Pretreatment of Gibberellic Acid}

\begin{abstract}
This research was carried out to determine the effects of salt stress with pre applications in different doses of Gibberellic Acid $\left(\mathrm{GA}_{3}\right)$ on germination of sweet william (Dianthus barbatus L.) seeds. Sweet william (Dianthus barbatus L.) was used as herbal material and the seeds were subjected to nine different applications. In the study, while the highest germination rate $(83.50 \%)$ of sweet william seeds was found in watered with distilled water applied 40 ppm $\mathrm{GA}_{3}$ pretreatment, the lowest germination rate $(4.00 \%)$ was determined on seeds pre-treated with distilled water and watered with $100 \mathrm{mM} \mathrm{NaCl}$. The lowest mean germination time had been found in the seeds applied $20 \mathrm{ppm} \mathrm{GA}_{3}$ pretreatment and watered with distilled water with 3.10 (day). Salinity blocked the germination of sweet william seeds in depending on the concentrations. Pretreatment of GA 3 plant growth regulators before germination, effect of inhibiting germination of salt stress had considerably diminished.
\end{abstract}

Keywords: Dianthus barbatus, gibberellic acid $\left(\mathrm{GA}_{3}\right)$, seed germination, salinity stress

\section{GíRiş}

Türkiye'de süs bitkileri üretim alanları 2014 y1lında 49.019 da'a ulaşmıştır. Süs bitkileri ihracatımız ise 82.969 milyon \$'dır. Ülkemizdeki süs bitkileri üretim alanlarının \%73.43'ünü dış mekan süs bitkileri, \%23.20'ini kesme çiçekler, \%2.21'ini iç mekan süs bitkileri ve \%1.16'sını doğal çiçek soğanları oluşturmaktadır. Süs bitkileri üretim alanları iller bazında değerlendirildiğinde, İzmir ili $\% 28.35$ 'lik pay ile ilk sirada yer alırken, bunu $\% 25.79^{\prime}$ lük payla Sakarya ve \%11.60'lık payla Antalya ili izlemektedir (Anonim, 2015a).

Süs bitkileri yetiştiriciliğinde önemli türlerden biri olan Caryophyllaceae familyasına ait hüsnüyusuf (Dianthus barbatus L.), Kuzey ve Güney Avrupa kökenli bir bitkidir (Anonim, 2008a). Yaşamlarını 23 yıl sürdüren hüsnüyusuflar bahçelerde çiçek parteri oluşturmada kullanılan, aynı zamanda kesme çiçek olarak da önemi bulunan bir karanfil türüdür. En uygun gelişme sıcaklığ $1 \quad 10^{\circ} \mathrm{C}$ 'dir. Çimlenme ortamının sicaklığ $15-18^{\circ} \mathrm{C}$ dolayında tutulduğu takdirde 8-10 gün içerisinde çimlenme gerçekleşmektedir. Tohumdan çiçeklenmeye kadar geçen süre 28 hafta dolayındadır (Hatipoğlu ve Gülgün, 1999).

Tohum ekimi ve tohumun uygun koşullarda çimlendirilmesi, bitkisel üretimin ilk ve en önemli aşamasını oluşturmaktadır (Yıldız vd.,2007; Karakurt vd., 2010). Bu aşamada tohum kabuğu (Esechie, 1995), tohum yaş1 (Smith ve Dobrenz, 1987), dormansi (Khan ve Ungar, 1984) gibi birçok bitkisel faktör ve sıcaklık (Khan ve Ungar, 1984), 1şık (De Villiers vd., 1994; Hartmann vd., 1990), su kullanılabilirliği (Khan ve Ungar, 1984) gibi çevresel faktör çimlenmeyi doğrudan etkilemektedir. Çimlenme, çıkış ve erken fide döneminde, tohum ve fideler fizyolojik ve çevresel stres faktörlerine karşı çok hassastırlar. Bitkilerde büyüme, gelişme ve metabolizmayı etkileyen ya da engelleyen durumlara stres adı verilmektedir. Stres faktörleri, bitkiler üzerine etkilerini çoğunlukla, eş zamanlı ve kombine şekilde göstermektedirler. Stres faktörleri, orijinlerine göre abiyotik ve biyotik stres faktörleri olmak üzere iki grupta incelenebilmektedir (Anonim, 2015b). 
Abiyotik stres faktörlerinden biri olan tuzluluk tarım yapılan toprakları olumsuz etkilemekte, bu topraklarda yetişen bitkilerde pek çok olumsuzluklara neden olmaktadir (Yılmaz vd., 2011). Toprak tuzluluğu, bitkinin transpirasyonunu, solunumunu, su alımını, kök ve bitki gelişimini olumsuz yönde etkilemektedir. Bunun sonucunda hormonal dengede bozulma, fotosentezde azalma (Leopold ve Willing, 1984), nitrat alımı düşmesi sonucunda protein sentezinde azalma görülmektedir (Dölarslan ve Gül, 2012). Ayrıca tuzlu topraklarda aşırı miktarda bulunan $\mathrm{Na}$ ve $\mathrm{Cl}$ gibi iyonların neden olduğu toksik etki ve bitki iyon dengesinde bozulmalar (Siegel vd., 1980; Flowers ve Yeo, 1981; İnal vd., 1995), bitkinin farklı bölgelerine besin alımı ve taşınmasında problemler (Leopold ve Willing, 1984) meydana gelmektedir.

Bitki türlerinin toprak tuzluluğuna tepkisi farklılık gösterebilmektedir. Türlerin tuza tepkilerinin belirlenmesinde çimlenme ve fide gelişim dönemleri üzerinde daha fazla durulmaktadır (Van Hoorn vd., 2001). Toprağın yüksek oranda tuz içermesi çimlenme döneminde tohumun bünyesine su alımını engellemekte bu da çimlenmeyi olumsuz etkilemektedir (Mansour, 1994; Cuartero ve Fernandez-Munoz 1999; Misra ve Dwivedi, 2004). Dolayısıyla doza bağlı olarak çimlenme oranında azalma veya tamamen engelleme, çimlenme ve fide gelişiminde gecikmeye sebep olmaktadır (Katerji vd., 2000; Almansouri vd., 2001). Zarar görmeden çimlenme aşamasından fide aşamasına geçmek optimum toprak koşulların sağlanması ile mümkün olabilmektedir.

Çimlenmesi geç ve zor olan küçük embriyolu bazı sebze tohumlarının olumsuz toprak koşullarındaki çimlenmesini iyileştirmek ve homojen fide çıkışını sağlamak amacıyla yapılan araştırmalarda (Brocklehurst vd., 1984; 1987a; 1987b; Yanmaz ve Özdil, 1992) ekim öncesi bazı ön uygulamalar sonunda çimlenme ve çıkış hızı ile oranlarının arttığı, erken ve homojen fide çıkışı sağlandığı belirlenmiştir (Duman ve Eşiyok, 1998). Priming uygulamaları olarak adlandırılan tohumların katlamaya tabi tutulması, iriliklerine göre sınıflandırılmaları, ekim öncesi 1slatma, asitlerle aşındırma, büyümeyi düzenleyiciler, vitaminler, çimlendikten sonra jel halinde ekilmesi, besin maddeleri veya osmotik çözeltilerde tutma, kaplama ve bantlama gibi uygulamalar ekim öncesi ön uygulamalardandır (Hartman vd., 1990; Hilhorst ve Karssen, 1992; Ercişli vd., 1999; Yamaguchi ve Kamiya, 2002; Demirkaya, 2006; Karakurt vd., 2010).

Bitki büyüme ve gelişiminde çeşitli fizyolojik etkilere sahip olan bitki hormonlarının tohum çimlenmesinde de çok önemli rolleri bulunmaktadır. Gibberalinler, tohum ve tomurcuk dormansisinin ortadan kaldırılmasında, tohum çimlenmesinin kontrolü ve uyarılmasında etkili olmalarından dolayı yaygın şekilde priming yöntemi olarak kullanılmaktadır. Gibberalinler, tohum çimlenmesi evresinde rol alan enzimlerin uyartılmasında rol almaktadır. Bununla birlikte, çimlenmenin sonraki aşamasında gibberalinler embriyodan endosperme taşınıp $\alpha$-amilaz enzimini uyararak gerekli enerjiyi sağlamak için nişastanın şekere dönüşmesinde rol oynamaktadır (Hartmann ve ark., 1990; Hilhorst ve Karssen, 1992; Karakurt vd., 2010). Ayrica Gibberalinler embriyonun büyüme potansiyelini uyararak, endospermde üretilen endo- $\beta$-mannanaz endosperm hücre duvarlarının bozulmasını sağlayarak çimlenmeye yardımcı olabilmektedir (Yamaguchi ve Kamiya, 2002; Karakurt vd., 2010).

Uygulanan $\mathrm{GA}_{3}$ konsantrasyonu ve süresi çimlenme üzerinde önemli etkiye sahiptir (Zhang, 2003; Duman, 2006; Anonim, 2008b). Gibberellik asit $\left(\mathrm{GA}_{3}\right)^{\prime}$ 'in, diş ortamdaki bitki tepkilerini düzenleme ile ilgili olduğu bilinmektedir (Chakrabarti ve Mukherji, 2003). GA, ün su kullanım etkinliği üzerine tuz stresinin etkilerini hafiflettiği bildirilmiştir (Aldesuquy ve Ibrahim, 2001). Çavuşoğlu vd., (2007)'nin yaptığı çalışma sonucunda araştırmada kullanılan bitki büyümesini düzenleyici maddeler arasında tuz stresini azaltıcı en büyük etkiyi $\mathrm{GA}_{3}$ yapmıştır.

$\mathrm{GA}_{3}$ 'ün çimlenme üzerine olan etkisi konsantrasyon, süre ve bitki türüne göre değişmektedir. Bu nedenle, tuzlu topraklarda yapılan süs bitkileri yetiştiriciliğinde tohum çimlenmesinde tuzluluğun olumsuz etkilerini hafifletmek için uygun ölçümleri geliştirme çalışmaları değer kazanmaktadır (Zheng vd., 2009; Kayış, 2014). Bu çalışmada, tuzluluğun hüsnüyusufun tohum çimlenmesi üzerindeki olumsuz etkisinin, $\mathrm{GA}_{3}$ bitki büyüme düzenleyicisinin tohumlara çimlenme öncesinde uygulanmasıyla hafifletilmesi amaçlanmıştır.

\section{MATERYAL VE YÖNTEM}

Çalışma 2015 yılında Atatürk Üniversitesi Ziraat Fakültesi Bahçe Bitkileri Bölümü'nün Sebzecilik Laboratuvarı'nda yürütülmüştür. Araştırmada Dianthus barbatus (hüsnüyusuf) türüne ait tohumlar kullanılmış ve tohumlar ticari bir firmadan temin edilmiştir. Hüsnüyusuf tohumları, \% 2.5 (v/v) sodyum hipoklorid ile 10 dakika yüzey sterilizasyonu yapılarak yedi kez saf sudan geçirilmiş ve steril kabın içinde kurumaya bırakılmıştır (Azizi vd., 2011).

Araştırma, 2 faktörlü tam şansa bağlı deneme deseninde, 4 tekerrürlü ve 9 farklı uygulama halinde petrilerde yürütülmüştür (Çizelge 1).

Çimlendirme denemelerinde tohum ön uygulamaları olarak $\mathrm{GA}_{3}$ 'ün 2 farklı dozu (20 ppm ve $40 \mathrm{ppm})$ ve distile su $\left(\mathrm{H}_{2} \mathrm{O}\right)$ içinde hüsnüyusuf 
tohumları $20 \pm 1{ }^{\circ} \mathrm{C}$ 'de karanlık koşullarda 24 saat süre ile bekletilmiştir. Bekleme süresi sonrasında tohumlar süzülüp iki kat kurutma kâğıdı yerleştirilen her bir steril petri içine 50 adet tohum konulmuştur. Hazırlanan farklı dozlardaki $\mathrm{NaCl}$ solüsyonlarından (50 ve $100 \mathrm{mM}$ ) ve saf sudan ilgili her petrideki tohumların su ihtiyacı için $5 \mathrm{ml}$ uygulanmıştır. Uygulama gören tohumlar $25{ }^{\circ} \mathrm{C}$ sicaklık koşullarında çimlenme ve çıkış testine alınmıştır. Tohumların başlangıç canlılıkları, ISTA (1996) kurallarına göre belirlenmiştir. Çimlendirme testleri 10x2 çaplı petri kaplarında çift katlı kurutma kâğıtları arasında $25^{\circ} \mathrm{C}^{\prime} \mathrm{de} 4 \times 50$ tohum üzerinden 14 gün sürdürülmüştür (ISTA, 1996).

Çizelge 1. Hüsnüyusuf tohumlarına yapılan uygulamalar

\begin{tabular}{lc}
\hline Ön Uygulamalar & NaCl Dozları $(\mathrm{mM})$ \\
\hline Saf su (Kontrol) & 0 \\
Saf su & 50 \\
Saf su & 100 \\
\hline $20 \mathrm{ppm} \mathrm{GA}$ & 0 \\
$20 \mathrm{ppm} \mathrm{GA}$ & 50 \\
$20 \mathrm{ppm} \mathrm{GA}$ & 100 \\
\hline $40 \mathrm{ppm} \mathrm{GA}$ & 0 \\
$40 \mathrm{ppm} \mathrm{GA}$ & 50 \\
$40 \mathrm{ppm} \mathrm{GA}$ & 100 \\
\hline
\end{tabular}

Ortalama çimlenme süresi (gün): Araştırmada tohumların çimlenme ve ortalama çimlenme süreleri Orchard, (1977) ve Al-Mudaris (1998)'e göre belirlenmiştir.

Çimlenme oranı (\%): $4 \times 50$ adet tohum petri kaplarına konarak, etüvde çimlendirilmiş, her petri kabında çimlenen tohum sayısının, toplam tohum sayısına oranı 100 ile çarpılarak bulunmuştur (Maquire, 1962).
Sonuçlar; SPSS (Statistical Package for Social Sciences, Version 22.0) istatistik programında varyans analizine göre değerlendirilmiştir. Analiz sonuçlarına ait tamamlayıcı istatistikleri ve önem durumları tablolar halinde verilmiştir. Uygulamalar arasındaki farklığının önem derecesini belirlemek için Duncan ( $\mathrm{p}=0.05$ veya 0.01 ) testi yapılmıştır. Oran $(\%)$ olarak sunulan veriler ise varyans analizi uygulanmadan önce $\mathrm{y}=\arcsin [\operatorname{sqr}(\mathrm{x} / 100)]$ formülü kullanilarak açı değerlerine dönüştürülmüştür.

\section{ARAȘTIRMA SONUÇLARI}

Araştırmada, uygulamaların çimlenme oranı üzerine etkisinin istatistiki olarak önemli, ortalama çimlenme süresi üzerine etkisinin ise önemsiz olduğu belirlenmiştir (Çizelge 2).

Hüsnüyusuf tohumlarında ortalama en yüksek çimlenme oranının \% 59.33 ile $\mathrm{GA}_{3} 40 \mathrm{ppm}$ ön uygulamasından elde edildiği ve ikinci sırada \% 57.16 ile $\mathrm{GA}_{3} 20$ ppm ön uygulamasından sağlandığı ve kendi aralarında önemli fark oluşturmadıkları Çizelge 2'de görülmektedir. Hüsnüyusuf tohumlarında en düşük çimlenme oranı \% 48.16 ile Kontrol (saf su) uygulamasında kaydedilmiştir. Tohumlarda, ortalama en yüksek çimlenme oranı \% 80.66 ile $0 \mathrm{mM}$ (sulama suyu saf su) uygulamasindan ve ikinci surada \% 65.00 ile $50 \mathrm{mM}$ dozu uygulamasından sağlandığı tespit edilmiş ve aralarında istatiksel anlamda önemli farkın oluştuğu belirlenmiştir. En düşük çimlenme oranı ise \% 19.00 ile $100 \mathrm{mM}$ uygulamasında gözlenmiştir. $\mathrm{NaCl}$ dozları çimlenme oranına olumsuz etkide bulunmuştur. Bu nedenle, en yüksek çimlenme oranı $0 \mathrm{mM}$ uygulamasında gerçekleşmiştir. En yüksek (\% 83.50) çimlenme oranı 40 ppm $\mathrm{GA}_{3}$ ile ön uygulama görmüş hüsnüyusuf tohumlarının saf su ile $(0 \mathrm{mM}$ dozlu) sulanan uygulamadan elde edilmiştir.

Çizelge 2. $\mathrm{GA}_{3}$ ön uygulamasına tabi tutulmuş olan hüsnüyusuf tohumlarının farklı dozlardaki $\mathrm{NaCl}$ koşullarının çimlenme oranı (\%) ve ortalama çimlenme süresi (gün) üzerine etkileri

\begin{tabular}{lllll}
\hline \multirow{2}{*}{ Uygulamalar } & \multicolumn{4}{c}{ Çimlenme oranı (\%) } \\
\cline { 2 - 5 } Kontrol (Saf su) & $77.50^{* * * a b c}$ & $50 \mathrm{mM}$ & $100 \mathrm{mM}$ & Ortalama \\
$\mathrm{GA}_{3} 20 \mathrm{ppm}$ & $81.00^{\mathrm{ab}}$ & $63.00^{\mathrm{c}}$ & $4.00^{\mathrm{e}}$ & $48.16^{* * *} \mathrm{~B}$ \\
$\mathrm{GA}_{3} 40 \mathrm{ppm}$ & $83.50^{\mathrm{a}}$ & $65.00^{\mathrm{abc}}$ & $25.50^{\mathrm{d}}$ & $57.16 \mathrm{~A}$ \\
Ortalama & $80.66^{* * *} \mathrm{~A}$ & $67.00^{\mathrm{abc}}$ & $27.50^{\mathrm{d}}$ & $59.33 \mathrm{~A}$ \\
\cline { 2 - 5 } & \multicolumn{4}{c}{ Ortalama çimlenme süresi (gün) } \\
\cline { 2 - 5 } Uygulamalar & $0 \mathrm{mM}$ & $50 \mathrm{mM}$ & $100 \mathrm{mM}$ & Ortalama \\
Kontrol (Saf su) & $3.45^{\mathrm{ns}}$ & 3.8 & 3.00 & $3.42^{\mathrm{NS}}$ \\
$\mathrm{GA}_{3} 20 \mathrm{ppm}$ & 3.10 & 3.47 & 4.66 & 3.74 \\
$\mathrm{GA}_{3} 40 \mathrm{ppm}$ & 3.14 & 3.65 & 5.40 & 4.07 \\
Ortalama & $3.23^{*} \mathrm{~B}$ & $3.64 \mathrm{AB}$ & $4.35 \mathrm{~A}$ & \\
\hline
\end{tabular}

NS: NS: $p>0,05$ de önemsiz, ${ }^{* *} \mathrm{P}<0.01$ ve ${ }^{* * * *}<<0.001$ olasılık düzeyinde istatistiki olarak önemlidir. Not: Aynı harfle gösterilen ortalamalar arasında $\% 5$ önem seviyesinde farkl11lk yoktur. 


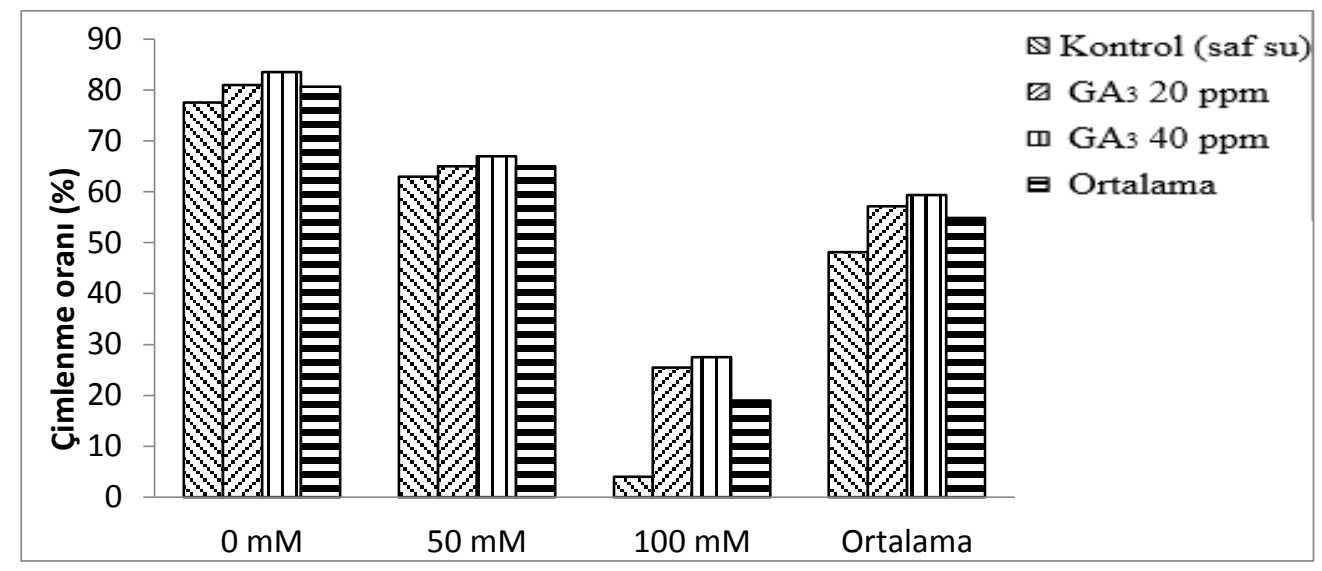

Şekil 1. $\mathrm{GA}_{3}$ ön uygulamasına tabi tutulmuş olan hüsnüyusuf tohumlarının farklı dozlardaki $\mathrm{NaCl}$ koşullarının çimlenme oranına etkisi

$50 \mathrm{mM} \mathrm{NaCl}$ konsantrasyonlu su ile sulanan $20 \mathrm{ppm}$ ve $40 \mathrm{ppm} \mathrm{GA}_{3}$ ile ön uygulama görmüş hüsnüyusuf tohumlarının çimlenme oranı sırasıyla $\% 65.00$ ve $\%$ 67.00 olarak tespit edilmiştir. $40 \mathrm{ppm} \mathrm{GA}_{3}$ ile ön uygulama görmüş hüsnüyusuf tohumlarının $0 \mathrm{mM}$ dozlu solüsyon ile sulanan uygulamasıyla aynı grupta yer almalarından dolayı aralarında istatiksel anlamda önemli bir farkın olmadığı belirlenmiştir. En düşük (\% 4.00) çimlenme oranı saf su ile ön uygulama görmüş hüsnüyusuf tohumlarının $100 \mathrm{mM}$ dozlu solüsyon ile sulanan uygulamadan elde edilmiştir (Çizelge2; Şekil 1).

Hüsnüyusuf tohumlarında ortalama en yüksek ortalama çimlenme süresi 4.07 (gün) ile $\mathrm{GA}_{3} 40$ ppm dozlu ön uygulamasından elde edildiği ve ikinci sırada 3.74 (gün) ile $\mathrm{GA}_{3} 20 \mathrm{ppm}$ dozlu ön uygulamasından sağlandığı Çizelge 2'te görülmektedir. Tohumlarda en düşük ortalama çimlenme süresi 3.42 (gün) ile kontrol (saf su) uygulamasında kaydedilmiştir. Ancak, elde edilen bu verilerin kontrol uygulaması ile karşılaştırıldığında (p>0.05) istatiksel olarak önemli olmadığ belirlenmiștir. Hüsnüyusuf tohumlarında ortalama çimlenme süresi ortalaması farklı $\mathrm{NaCl}$ konsantrasyonlarında istatiksel olarak önemli $(\mathrm{p}<0.05)$ bulunmuştur, ancak aynı grupta yer almalarından dolayı aralarında farkın olmadığ belirlenmiştir. En yüksek ortalama çimlenme süresi 4.35 (gün) ile $100 \mathrm{mM}$ uygulamasında tespit edilmiștir. $\mathrm{NaCl}$ dozları ortalama çimlenme süresine olumsuz etkide bulunmuștur. En yüksek (5.40 gün) ortalama çimlenme süresi $40 \mathrm{ppm} \mathrm{GA}_{3}$ ile ön uygulama görmüş hüsnüyusuf tohumlarının $100 \mathrm{mM}$ dozlu solüsyon ile sulanan uygulamadan elde edilmiştir. En düşük (3.00 gün) ortalama çimlenme süresi saf su ile ön uygulama görmüş hüsnüyusuf tohumlarının $100 \mathrm{mM}$ dozlu solüsyon ile sulanan uygulamada gözlenmiştir. Farklı dozlarda $\mathrm{GA}_{3}$ ve $\mathrm{NaCI}$ uygulanan hüsnüyusuf tohumlarının ortalama çimlenme süresi değerlerinin istatiksel olarak önemli olmadığ $(p>0.05$ ) belirlenmiştir (Çizelge 2; Şekil 2).

\section{TARTIŞMA VE SONUÇ}

Tohumlarda ortalama en yüksek çimlenme oranı sirasiyla $40 \mathrm{ppm} \mathrm{GA}_{3}+0 \mathrm{mM}$ ve $20 \mathrm{ppm} \mathrm{GA}_{3}+0 \mathrm{mM}$ ppm $\mathrm{GA}_{3}$ uygulamalarından elde edilmiş ancak bu iki uygulama arasındaki farklılık istatistiki olarak önemsiz bulunmuştur. Benzer bulgular Karssen (1995) tarafindan bildirilmiștir.

Çalışmada, tuzluluk, konsantrasyonuna bağlı olarak hüsnüyusuf tohumlarının çimlenmesini engellemiştir. Tuzun tohumlarda çimlenmeyi engelleyici etkisi, pek çok araștırmada ortaya konmuştur (Öztürk vd., 1994; Ghoulam ve Fores, 2001; Gulzar ve Khan, 2002; Çavuşoğlu vd., 2007). Çimlenme oranının azalmasına yüksek tuz konsantrasyonunun su alımını engellemesi, tuzun toksik etki yapması ve çimlenme sırasında gerekli olan enzimlerin tuz stresinden dolayı aktif hale gelememesinin neden olduğu bildirilmektedir (Siegel vd., 1980; Flowers ve Yeo, 1981; Mansour 1994; İnal vd., 1995; Essa 2002; Sadeghian ve Yavari 2004).

Araştırmamızın sonucunda çimlenme oranı ile elde ettiğimiz değerlerin Okçu, vd., (2005)'nın bezelyede; Tepe vd., (2011)'nın biberde; Çavușoğlu ve Kabar (2007)'nın turpta; Mufwanzala ve Dikinya (2010)'nın havuç ve ispanakta elde ettiği bulgularla uyum içinde bulunmuştur. Aynı zamanda benzer bulgular Azizi, vd., (2011)'nin hüsnüyusufta; Haiping, vd. (2012)'nin çin karanfili ve kır karanfilinde yapmış olduğu çalışmada da elde edildiği bildirilmiștir. Diğer taraftan, çimlenme öncesi yaptığımız $\mathrm{GA}_{3}$ ön uygulamaları, tuz stresinin hüsnüyusuf tohumlarının çimlenme engelleyici etkisini önemli ölçüde ortadan kaldırmıştır. Steppuhn vd., (2001) ve Dumlupinar, (2005), artan tuz konsantrasyonlarının tüm bitkilerde çimlenme oranını azalttığını bildirmişlerdir. 


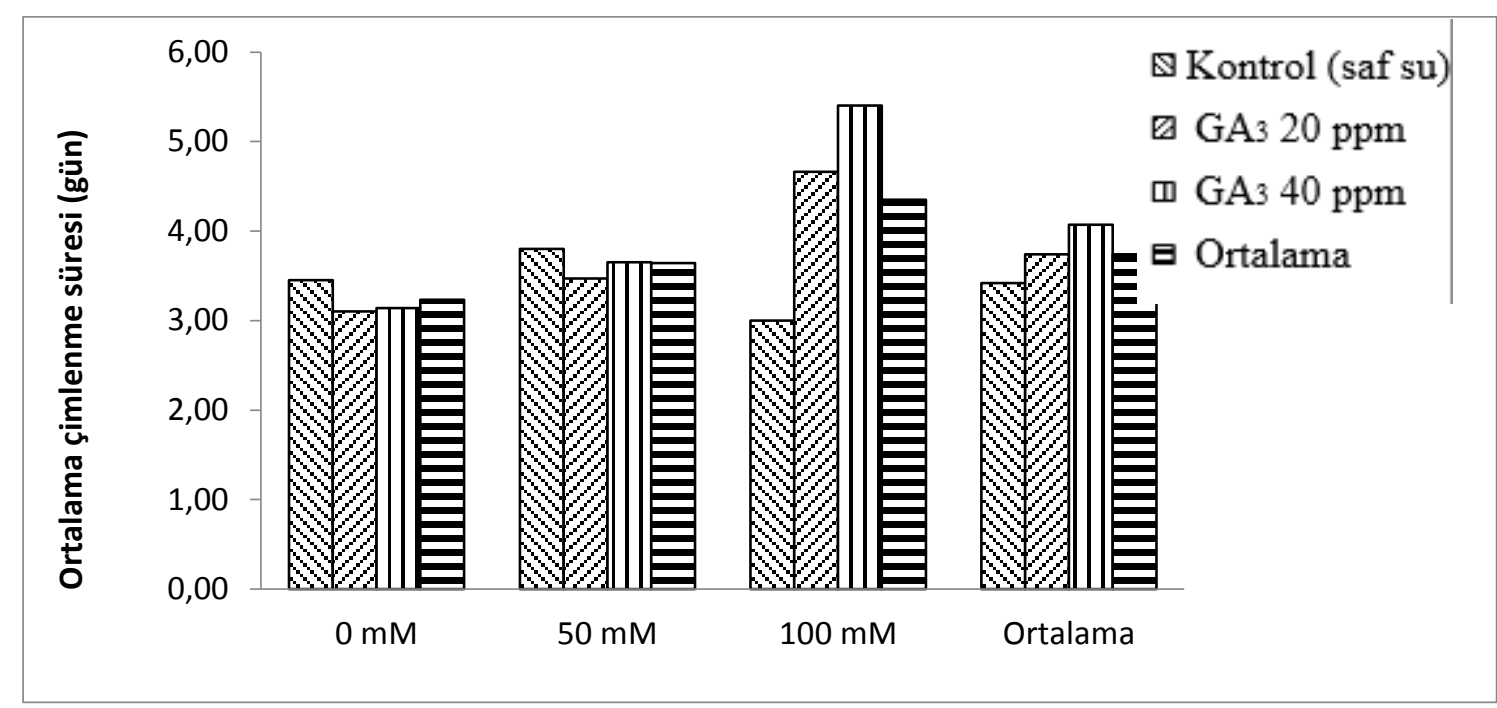

Şekil 2. $\mathrm{GA}_{3}$ ön uygulamasına tabi tutulmuş olan hüsnüyusuf tohumlarının farklı dozlardaki NaCl koşullarının ortalama çimlenme süresine etkisi

Söz konusu büyüme düzenleyicileri, tuzluluktan zarar gören hücre membranlarının stabilize edilmesini sağlayarak (Taylor ve Cosgrove, 1989), hidrolitik enzimlerin sentezini teşvik ederek (Kaur vd., 1998), hücre bölünmesi (Lıu ve Loy, 1976), protein ve nükleik asit miktarlarını artırarak (Mozer, 1980), veya tuz teşvikli ABA inhibisyonunu ortadan kaldırarak (Khan ve Ungar, 2001) olumlu etki yapabilmektedir.

Bitkisel üretim açısından tuzluluk en önemli abiyotik stres faktörlerinden biridir. Küresel ısınma sonucunda meydana gelen iklimsel değişimler, günümüzde tarımsal alanlarda kuraklığın yanında tuzluluğun da giderek artmasına neden olmaktadır. Bununla birlikte hüsnüyusuf bahçelerde çiçek parteri oluşturmada kullanılan, aynı zamanda kesme çiçek olarak da önemi bulunan hafif kokulu çiçekleri olan bir türdür. Çalışmamızda farklı dozlardaki (40 ppm ve $20 \mathrm{ppm}) \mathrm{GA}_{3}$ ön uygulamaları $\mathrm{NaCl}$ stresinin tohum çimlenmesi üzerindeki olumsuz etkisini hafifletmede önemli bir etkinlik göstermiştir. Buna göre, çalışmamızda $\mathrm{GA}_{3}$ ön uygulamalarının, tuz stresinin çimlenme esnasında yol açtı̆̆ 1 olumsuz etkileri gidermede farklı derecelerde etkinlik göstermeleri beklenmeyen bir durum değildir.

Sonuç olarak, hüsnüyusuf tohumlarının çimlenme öncesi $\mathrm{GA}_{3}$ ön uygulamaları ile tuz stresinin neden olduğu çimlenme engelleyici etki önemli ölçüde ortadan kaldırılabilecektir.

\section{KAYNAKLAR}

Aldesuquy, H.S., Ibrahim, A.H. 2001. Interactive effect of seawater and growth bio regulators on water relations, absicisic acid concentration and yield of wheat plants. J. Agron. Crop Sci., 187, 185-193.
Almansouri, M., Kinet, J.M., Lutts, S. 2001. Effect of salt and osmotic stresses on germination in durum wheat (Triticum durum Desf.) Plant Soil, 231, 243-254.

Al-Mudaris, M. A. 1998. Notes on various parameters recording the speed of seed germination. Der Tropenlandwirt-Journal of Agriculture in the Tropics and Subtropics, 99(2), 147154.

Anonim, 2008a. http://cicek-cicekci-cicekcilik.blogspot.com.tr/ 2008/09/hsnyusuf-dianthus-barbatus.html (Erișim tarihi: 01.06.2015).

Anonim, 2008b. Değișik dozlardaki $\mathrm{GA}_{3}$ uygulamalarının in vitro ve in vivo koşullarda doğal karanfil türlerinden Dianthus calocephalus Boiss. tohumlarının çimlenmesi üzerine etkileri.http://ziraat.harran.edu.tr/kongre/Bildiriler/188 DenizHAZAR.pdf.

Anonim, 2015a. https://www.google.com.tr/search?q=Dianthus+ barbatus\&biw $=($ Erişim tarihi 15.05 .2015$)$

Anonim, 2015b. (www.agri.ankara.edu.tr/fcrops/1289 BITKILERDE_STRES.pdf). Erișim tarihi 15.05.2015.

Azizi, M., Chehrazi, M., Zahedi, S.M. 2011. Effects of salinity stress on germination and early growth of sweet william (Dianthus barbatus). Asian Journal of Agricultural Sciences, 3(6), 453-458.

Brocklehurst, P.A., Dearman J.A. 1984. Comparison of different chemical for osmotic treatment of vegetable seed. Ann. Appl. Biol., 105, 391-398.

Brocklehurst, P.A., Dearman, J., Drew, R.L.K. 1987a. Recent developments in osmotic treatment of vegetable seeds. Acta Hort., 215, 193-200.

Brocklehurst, P.A., Dearman, J., Drew, R.L.K. 1987b. Improving establishment of vegetable crops by osmotic seed treatments. Acta Hort., 198, 73-80.

Çavuşoğlu, K., Kılıç, S., Kabar, K. 2007. Arpa tohumlarının çimlenmesi sırasında gibberellik asit, kinetin ve etilen ile tuz stresinin hafifletilmesinde bazı morfolojik ve anatomik gözlemler. Sdü Fen Edebiyat Fakültesi Fen Dergisi (EDergi), 2(1), 27-40.

Çavuşoğlu,K., Kabar, K. 2007. The Effects of Pretreatments of Some Plant Growth Regulators on Germination and Seedling Growth of Radish Seeds Undersalin conditions. Dumlupınar Üniversitesi, Fen Bilim. Enst. Derg., 14, 27-36.

Chakrabarti, N., Mukherji, S., 2003. Effect of phytohormone pretreatment on nitrogen metabolism in vigna radiate under salt stress. Biol. Planta, 46, 63-66. 
Cuartero, J., Fernandez-Munoz, R. 1999. Effects of salinity on tomato. Sci Hortic, 78, 83-125.

De Villiers, A.J., Van Rooyen, M.W., Theron, G.K., Van De Venter, H.A., 1994. Germination of three Namaqualand pioneer spicies, as influenced by salinity, temperature and light, Seed Sci. Technol., 22, 427-433.

Demirkaya, M. 2006. Polietilenglikol ile osmotik koșullandırma ve humidifikasyon uygulamalarının biber tohumlarının çimlenme hızı ve oranı üzerine etkileri. Erciyes Üniv. Fen Bil. Enst. Dergisi, 22 (1-2), 223-228.

Dölarslan, M., Gül, E. 2012. Toprak bitki ilişkileri açısından tuzluluk. Türk Bilimsel Derlemeler Dergisi, 5 (2), 56-59.

Duman, İ. 2006. Domates tohumlarında çimlenme ve fide çıkışının iyileştirilmesi. Ege Üniversitesi. Ziraat Fak. Bahçe Bitkileri Bölümü. www.tuam.ege.edu.tr/dergi/ dergi1/domates.

Duman, İ., Eşiyok, D. 1998. Ekim öncesi PEG ve KH2PO4 uygulamalarının havuç tohumlarının çimlenme ve çıkış oranı ile verim üzerine etkileri. Tr. J. of Agriculture and Forestry, 22, 445-449.

Dumlupınar, Z. 2005. Elektrik Akımı ve Tuz Konsantrasyonlarının Makarnalık Buğdayda Çimlenmeye Etkisi. Yüksek Lisans Tezi, Kahramanmaraş Sütçü İmam Üniversitesi Kahramanmaraş, Türkiye.

Ercişli, S., A. Eşitken, M. Güleryüz. 1999. The effect of vitamines on the seed germination of apricots. Acta Hort., 488: 437440

Esechie, H.A., 1995. Partitioning of chloride ions in the germinating seed of two forage legumes under varied salinity and temperature regimes, Commun. Soil Sci. Plant Anal., 26, 3357-3370.

Essa, T.A. 2002. Effect of salinity stress on growth and nutrient composition of three soybean (Glycine max L. Merrill) cultivars. Journal of Agronomy and Crop Sci. 188, 86-93.

Flowers, T.J., Yeo, A.R. 1981. Variability in the resistance of sodium chloride salinity within rice (Oryza sativa L.) varieties. New Phytology, 88, 363-373.

Ghoulam, C., Fores, K. 2001. Effect of salinity on seed germination and early seedling growth of sugar beet (Beta vulgaris L.). Seed Science Technology, 29,357-364.

Gulzar, S., Khan, Ma. 2002. Alleviation of salinity-induced dormancy in perennial grasses. Biologia Plantarum, 45(4), 617-619.

Haiping, C., Xiuyun, Y., Ye, Z., Jun, B. 2012. Effect of $\mathrm{NaCl}$ Stress on Seed Germination of Dianthus chinensi and Dianthus plumarius. Journal of Shanxi Agricultural University (Natural Science Edition), 3, 016.

Hartmann, H.T., Kester, D.E., Davies, F.T. 1990. Plant Propagation. Principles of Propagation by Seed. 647 p.

Hatipoğlu, A., Gülgün, B. 1999. Tek ve çok yıllık mevsimlik ciçekler. Kent matbaas1, 208. İzmir.

Hilhorst, H.W.M. and C.M. Karssen. 1992. Seed dormancy and germination: The Role of absisic acid and gibberalins and the importance of hormone mutants. Plant Growth Regulation, 11: 225-238.

İnal, A., Günes, A., Aktas, M. 1995. Effects of chloride and partial substitution of reduced forms of nitrogen for nitrate in nutrient solution of the nitrate, total nitrogen and chlorine contents of onion. Journal of Plant Nutrition, 18, 22192227.

ISTA, 1996. International rules for seed testing, Edition 1996/6, International Seed Testing Association, Zurich. Switzerland. $196 \mathrm{p}$.

Karakurt, H., Aslantaş, R., Eşitken, A. 2010. Tohum Çimlenmesi ve Bitki Büyümesi Üzerinde Etkili Olan Çevresel Faktörler ve Bazı Ön Uygulamalar. Uludağ Üniversitesi Ziraat Fakültesi Dergisi, 24(2).

Karssen, Cm. 1995. Hormonal regulation of seed development, dormancy, and germination studied by genetic control. In: KIGEL J. \& GOLILI G. (Eds.) Seed Development and Germination. Marcel Dekker, New York, 333:350.
Katerji, N., van Hoorn, J.W., Hamdy, A., Mastrorilli, M. 2000. Salt tolerance classification of crops according to soil salinity and to water stress day index. Agricultural Water Management, 43, 99-109.

Kaur, S., Gupta, Ak., Kaur, N. 1998. Gibberellin A3 reverses the effect of salt stress in chickpea (Cicer arietinum L.) seedlings by enhancing amylase activity and mobilization of starch in cotyledons. Plant Growth Regulation, 26, 85-90.

Kayış, Sariye Uzun., 2014. Bazı mercimek (Lens culinaris Medic.) çeşitlerinin çimlenme ve fide döneminde tuza toleransı. Diss. Selçuk Üniversitesi Fen Bilimleri Enst., 54s, Konya.

Khan, M.A., Ungar, I.A., 1997. Effects of light, salinity and thermoperiod on the seed germination of halophytes, Can. J. Bot., 75, 835-541.

Khan, Ma., Ungar, Ia. 2001. Role of dormancy regulating chemicals in release of innate and salinity-induced dormancy in Sporobolus arabicus Boiss. Seed Science Technology, 29, 299-306.

Leopold, A.C., Willing, R.P. 1984. Evidence of Toxicity Effects of Salt on Membranes. In: Salinity Tolerance in Plants, (eds. R.C. Staples and G.H. Toenniessen), pp. 67-76

Liu, Pdw., Loy Jb. 1976. Action of gibberellic acid on cell proliferation in the subapical shoot meristem of Watermelon seedlings. American Journal of Botany, 63, 700-704.

Mansour, M.M.F. 1994. Changes in growth, osmotic potential and cell permeability of wheat cultivars under salt stress. Biological Plant, 36: 429-434.

Maquire, J.D. 1962. Speed of germination aid in selection and evaluation for seedling emergence and vigor. Crop Science, 2, 176-177.

Misra, N., Dwivedi, U.N. 2004. Genotypic difference in salinity tolerance of green gram cultivars. Plant Sci., 166, 11351142

Mozer, Tj. 1980. Control of protein synthesis in Barley aleurone layers by the plant hormones gibberellic acid and abscisic acid. Cell, 20, 479-485.

Mufwanzala,N., Dikinya, O. 2010. Impact Of Poultry Manure and its Associated Salinity on The Growth and Yield of Spinach (Spinacea oleracea) and Carrot (Daucus carota). Int. J. Agric. Biol., 12, 489-494.

Okçu, G., Kaya, M.D., Atak, M. 2005. Effects of Salt and Drought Stresses on Germination and Seedling Growth of Pea (Pisum sativum L.). Turk. J. Agric. For., 29, 237-242.

Orchard, T. J. 1977. Estimating the parameters of plant seedling emergence. Seed science and technology, 5, 61-69.

Öztürk, M., Gemici, M., Özdemir, F., Keyikçi, N. 1994a. Tohum çimlenmesi olayında bitkisel hormonların ve çimlenme stimülatörünün tuz stresini azaltmadaki rolü, XII. Ulusal Biyoloji Kongresi, Edirne, s. 44-48.

Sadeghian, S.Y., Yavari, N. 2004. Effect of water-deficit stress on germination and early seedling growth in sugar beet. Journal of Agronomy and Crop Science 190,138-144.

Siegel, S. M., Siegel, B.Z., Massey, J., Lahne, P., Chen, J. 1980. Growth of Corn in Saline Water. Physiology Plant, 50, 7173.

Smith, S.E., Dobrenz A.K., 1987. Seed age and salt tolerance et germination in alfalfa, Crop Sci., 27, 1050-1056.

Steppuhn, H., Volkmar, K.M., Miller, P.R. 2001. Comparing canola American society of civil engineers, 619 pp, New York. Technology, 13, 281-297.

Taylor, A., Cosgrove, Dj. 1989. Gibberellic acid stimulation of Cucumber hypocotyl elongation: effects on growth, turgor, osmotic pressure, and cell Wall properties. Plant Physiology, 90, 1335-1340.

Tepe, A., Kaya, H., Batmaz, G., Özkan, C.F., Demirtas, E.I. 2011. Tuzlu Sulama Suyu Uygulamalarının Bazı Biber Saf Hatlarının Verimleri Üzerine Etkisi. Batı Akdeniz Tarımsal Araştırma Enstitüsü, 28(1), 1-11. 
Van Hoorn, J.W., Katerji, N., Hamdy, A., Mastrorilli, M. 2001. Effect of salinity on yield and nitrogen uptake of four grain legumes and on biological nitrogen contribution from the soil. Agricultural Water Management, 51, 87-98.

Yamaguchi, S. and Y. Kamiya. 2002. Gibberalins and lightstimulated seed germination. J. Plant Growth Regul., 20:369-376

Yanmaz, R., Özdil, A.H. 1992. Domates ve havuç tohumlarında ekim öncesi PEG (Polyethylenglycol) uygulamalarının çimlenme ve çıkıs oranı ile çıkıs süresi üzerine etkileri. Türkiye I. Ulusal Bahçe Bitkileri Kongresi. 25-27, İzmir, Cilt II..
Yıldız, M., Kasap, E., Konuk, M. 2007. Tuzluluk, Sicaklık ve Ișığın Tohum Çimlenmesi Üzerine Etkileri. Afyon Kocatepe Üni. Fen Bilimleri Dergisi, 7(1), 225-243.

Yılmaz, E., Tuna, M., Bürün, B. 2011. Bitkilerin tuz stresi etkilerine karşı geliştirdikleri tolerans stratejileri, C.B.Ü. Fen Bilimleri Dergisi, 7(1), 47-66.

Zhang, Y. 2003. Study on the effect of soaking peach rootstock seeds before stratification with GA on seed germination. Hort. Abst. 73(2), 1092.

Zheng, C., Jiang, D., Liu, F., Dai, T., Liu, W., Jing, Q., Cao, W. 2009. Exogenous nitric oxide improves seed germination in wheat against mitochondrial oxidative damage induced by high salinity. Environ. Exp. Bot., 67, 222-227. 